\title{
Identification of the notothenioid sister lineage illuminates the biogeographic history of an Antarctic adaptive radiation
}

Thomas J Near ${ }^{1,2^{*}}$, Alex Dornburg ${ }^{1}$, Richard C Harrington ${ }^{3}$, Claudio Oliveira ${ }^{4}$, Theodore W Pietsch ${ }^{5}$, Christine E Thacker ${ }^{6}$, Takashi P Satoh ${ }^{7}$, Eri Katayama ${ }^{7}$, Peter C Wainwright ${ }^{8}$, Joseph T Eastman ${ }^{9}$ and Jeremy M Beaulieu ${ }^{10}$

\begin{abstract}
Background: Antarctic notothenioids are an impressive adaptive radiation. While they share recent common ancestry with several species-depauperate lineages that exhibit a relictual distribution in areas peripheral to the Southern Ocean, an understanding of their evolutionary origins and biogeographic history is limited as the sister lineage of notothenioids remains unidentified. The phylogenetic placement of notothenioids among major lineages of perciform fishes, which include sculpins, rockfishes, sticklebacks, eelpouts, scorpionfishes, perches, groupers and soapfishes, remains unresolved. We investigate the phylogenetic position of notothenioids using DNA sequences of 10 protein coding nuclear genes sampled from more than 650 percomorph species. The biogeographic history of notothenioids is reconstructed using a maximum likelihood method that integrates phylogenetic relationships, estimated divergence times, geographic distributions and paleogeographic history.
\end{abstract}

Results: Percophis brasiliensis is resolved, with strong node support, as the notothenioid sister lineage. The species is endemic to the subtropical and temperate Atlantic coast of southern South America. Biogeographic reconstructions imply the initial diversification of notothenioids involved the western portion of the East Gondwanan Weddellian Province. The geographic disjunctions among the major lineages of notothenioids show biogeographic and temporal correspondence with the fragmentation of East Gondwana.

Conclusions: The phylogenetic resolution of Percophis requires a change in the classification of percomorph fishes and provides evidence for a western Weddellian origin of notothenioids. The biogeographic reconstruction highlights the importance of the geographic and climatic isolation of Antarctica in driving the radiation of cold-adapted notothenioids.

Keywords: Ancestral range estimation, Weddellian Province, Notothenioidei, Percomorpha

\section{Background}

The teleost fishes of the Southern Ocean are unlike any other marine fish fauna on Earth because a single clade of closely related species, the notothenioids, dominates the diversity, biomass and abundance [1,2]. The ecological importance of notothenioids is reflected in their role as a key component of Antarctic marine food webs and as the primary targets of fish harvesting in the Southern Ocean [3-7]. In addition, Antarctic notothenioids are one of the

\footnotetext{
* Correspondence: thomas.near@yale.edu

'Department of Ecology and Evolutionary Biology, Yale University, New Haven, CT 06520, USA

${ }^{2}$ Yale Peabody Museum of Natural History, New Haven, CT 06520, USA

Full list of author information is available at the end of the article
}

most compelling examples of adaptive radiation among ray-finned fishes $[1,8]$. They show numerous adaptations to polar environmental conditions, including antifreeze glycoproteins (AFGP) $[9,10]$, and interesting patterns of ecological and lineage diversification [10-12]. Despite the attention paid to notothenioids by evolutionary biologists for more than a century [13], and numerous studies investigating the phylogenetic relationships of notothenioids [14-23], the ability to place the diversification of this lineage into the broader context of acanthomorph teleost diversity has been limited because there is still uncertainty regarding the sister lineage of the clade [24].

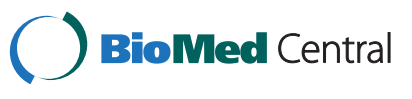

(c) 2015 Near et al. This is an Open Access article distributed under the terms of the Creative Commons Attribution License (http://creativecommons.org/licenses/by/4.0), which permits unrestricted use, distribution, and reproduction in any medium, provided the original work is properly credited. The Creative Commons Public Domain Dedication waiver (http:// creativecommons.org/publicdomain/zero/1.0/) applies to the data made available in this article, unless otherwise stated. 
Since the early 20th Century it has been clear that notothenioids are related to other percomorph teleosts $[25,26]$, but a confident resolution of their sister lineage has remained elusive for more than 100 years [24,27]. Previous phylogenetic hypotheses of notothenioid relationships based on morphology included the Zoarcoidei [28] or elements of the polyphyletic "trachinoids" as candidate sister lineages [22,29-36]. Molecular phylogenetic analyses consistently resolve notothenioids in the recently delimited species-rich percomorph clade Perciformes [sensu 10] that includes Percidae, Bembridae, Platycephalidae, Bembropidae, Gasterosteidae, Zoarcoidae, all of the Scorpaeniformes and the potentially non-monophyletic Serranidae [27,32,37-40]. Support for the specific sister lineage of notothenioids within the Perciformes in molecular phylogenetic analyses has included Percidae [27,32,41], Congiopodidae [42], Trachinidae [43], Bembropidae $[37,38]$, or a clade containing Percidae, Serranus and Bembrops [44]. Two studies with a broad sampling of percomorph lineages placed notothenioids in Perciformes, but did not provide a strongly supported hypothesis for their sister lineage $[39,40]$. This lack of resolution regarding the notothenioid sister lineage hinders our understanding of the evolutionary processes that underlie the origination of this Antarctic adaptive radiation.

The utilization of habitats in the subzero waters of the Southern Ocean represents one of the most extreme ecological transitions among teleost fishes $[1,9,45]$; however, the biogeographic history of notothenioid diversification is poorly understood. In addition to the Antarctic Clade [8], there are three other major notothenioid taxa (Bovichtidae, Pseudaphritis urvillii and Eleginops maclovinus) that are distributed in areas adjacent to the Southern Ocean including southern South America, the Falkland Islands, Tristan da Cunha, southern Australia and New Zealand [1,46-51]. The phylogenetic relationships of the major notothenioid lineages and their geographic distribution has led to the hypothesis that diversification of the clade was influenced by the breakup of Eastern Gondwana $[1,17,22,48]$, and estimated divergence times of notothenioids using relaxed molecular clocks appear consistent with the timing of Gondwanan fragmentation [8,44,52]. However, the multitude of candidate sister lineages to notothenioids includes clades that span a broad spectrum of geographic distributions that could potentially undermine the East Gondwanan biogeographic hypothesis. For example, if Percidae is the living sister lineage of notothenioids $[27,32,41]$, there will be limited insight into the origin of either clade from historical biogeographic reconstructions because percids exhibit a Holarctic distribution in freshwater habitats that is quite disjunct from the southern hemisphere cold-temperate, sub-Antarctic and Antarctic distribution of notothenioids. On the other hand, if Congiopodidae (racehorses and pigfish) and notothenioids were resolved as sister lineages, as inferred in a previous molecular phylogenetic analysis [42], their shared geographic distribution in the southern hemisphere would potentially strengthen the hypothesis of an East Gondwanan biogeographic pattern.

In this study, we investigate the phylogenetic resolution of notothenioids within the hyper-diverse Percomorpha $[8,10]$. A DNA sequence dataset of 10 nuclear genes used in several phylogenetic analyses of percomorph fishes $[10,40,53,54]$, including notothenioids [8], is expanded to include every taxon implicated in previous studies as being related to notothenioids. The phylogenetic analyses of this dataset, which includes more than 650 species of Percomorpha, provides a clear and well-supported hypothesis of the sister lineage of notothenioids. Phenotypic traits important in the study of notothenioid phylogeny were examined to determine if there is morphological support for the resolution of the notothenioid sister lineage in our molecular analyses. We time calibrated this new phylogenetic perspective of notothenioid relationships using Bayesian methods and integrated this phylogenetic framework with a likelihood-based model of ancestral area estimation to investigate the biogeographic history that underlies the notothenioid adaptive radiation.

\section{Results and discussion}

\section{Phylogenetic resolution of the notothenioid sister lineage}

The inferred phylogeny of acanthomorph teleosts resolves relationships among the major notothenioid lineages, namely Bovichtidae, Pseudaphritis, Eleginops and the Antarctic Clade that are consistent with previous inferences using morphology and molecular data $[8,16,17,20,22]$. Percophis brasiliensis is strongly supported as the sister lineage of notothenioids with a bootstrap score (BSS) of 100 (Figure 1). The expanded notothenioid clade that includes Percophis is nested within Perciformes; however, the placement of this lineage among other perciform clades is not well supported (Figure 1). The perciform clades identified as the notothenioid sister lineage in previous molecular phylogenies, Bembropidae, Percidae, Congiopodidae and Trachinidae, are not supported as more closely related to notothenioids than other perciforms in our tree (Figure 1); however, the inferred relationships of these clades relative to the clade containing Percophis and the traditional notothenioids are weakly supported (BSS $<70 \%$; Figure 1). The identification of Percophis as the sister lineage of all other notothenioids is less a testament to the phylogenetic utility of this particular dataset than simply a result of including the species in the 10 nuclear gene alignment. The only previous DNA sequencing of Percophis is the mitochondrial gene COI for barcode studies [55,56].

The addition of Percophis, Chrionema and Pteropsaron to the molecular phylogenetic dataset demonstrates that 


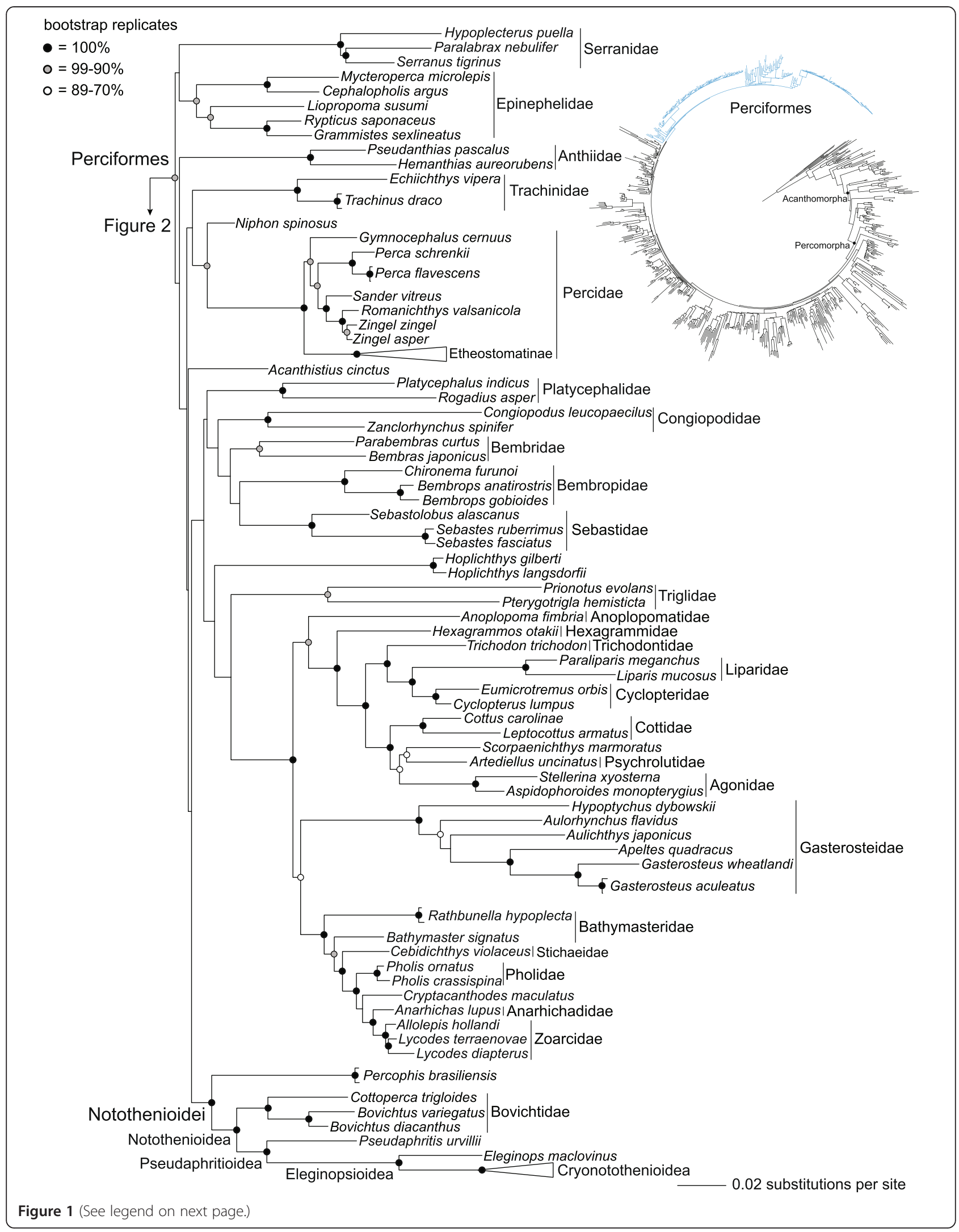


(See figure on previous page.)

Figure 1 Phylogeny of Perciformes inferred from a partitioned maximum-likelihood analysis of DNA sequences of 10 nuclear genes that resolves Percophis brasiliensis as the sister lineage of the Notothenioidea. This is a portion of a larger phylogenetic analysis of acanthomorph teleosts (inset phylogeny with Perciformes highlighted in blue). Filled black circles identify clades supported with a bootstrap score of $100 \%$, filled grey circles identify clades with a bootstrap score between $99 \%$ and $90 \%$, and unfilled white circles identify clades with a bootstrap score between $89 \%$ and 70\%. Polytypic and polygeneric higher-level taxonomic groups are labeled. The clades Acanthomorpha and Percomorpha are identified in the inset tree with filled black circles.

the three "percophid" subfamilies resolve in different areas of the percomorph phylogeny (Figures 1 and 2). The paraphyly of Percophidae, which traditionally includes Percophis, Bembropidae (Bembrops and Chrionema) and Hemerocoetinae (e.g., Acanthaphritis, Osopsaron and Pteropsaron) [57-59] is consistent with an earlier phylogenetic analysis of the 10 nuclear gene dataset that sampled Bembrops and Acanthaphritis and also did not result in monophyly of Percophidae [40]. We resolve Percophis and Bembropidae as nested within Perciformes, and Hemerocoetinae, sampled with Acanthaphritis and Pteropsaron, are resolved as the sister lineage of Limnichthys (Creediidae) (Figure 2). A clade containing Hemerocoetinae and Creediidae, as resolved in the molecular phylogeny (Figure 2), was also hypothesized from phylogenetic analysis of 61 morphological characters [60], and is a result that was predicted in other morphological studies that did not rely on optimization of discretely coded character states [33,61-63]. The resolution of notothenioids within "trachinoids" in a previous phylogenetic analysis was potentially the result of morphological synapomorphies shared with Percophis [30], but relationships were likely obfuscated by scoring morphological character states for "percophids" as a single taxon that comprised the polyphyletic assemblage comprising Bembrops, Percophis and Hemerocoetes $[31,64]$.

\section{Morphology and support for a clade containing notothenioids and Percophis}

Is there morphological evidence to support the molecular phylogenetic analysis that resolves Percophis as the sister lineage of notothenioids? Synapomorphies for notothenioids have not been identified and, instead, the lineage is diagnosed by a presumably unique combination

$$
\begin{aligned}
& \text { bootstrap replicates } \\
& \bullet=100 \% \\
& 0=99-90 \% \\
& 0=89-70 \%
\end{aligned}
$$

- Howella zina

Figure
"Acropomatidae"

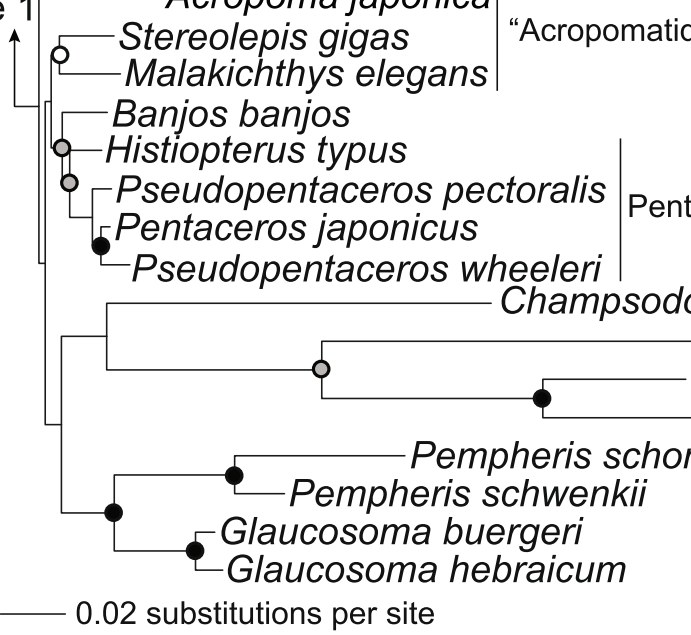

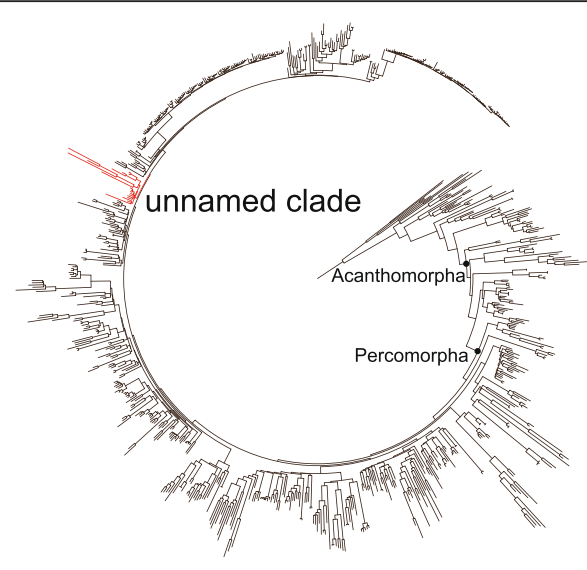

Limnichthys sp.|Creediidae Acanthaphritis unoorum -Pteropsaron springeri |"Percophidae"

Figure 2 Phylogeny of an unnamed clade of Percomorpha as resulting from an analysis of acanthomorph teleosts (inset phylogeny with the unnamed clade highlighted in red), inferred from a partitioned maximum-likelihood analysis of DNA sequences of 10 nuclear genes. Filled black circles identify clades supported with a bootstrap score of 100\%, filled grey circles identify clades with a bootstrap score between 99\% and 90\%, and unfilled white circles identify clades with a bootstrap score between $89 \%$ and $70 \%$. Polytypic and polygeneric higher-level taxonomic groups are labeled. The clades Acanthomorpha and Percomorpha are identified in the inset tree with filled black circles. 
of morphological character states: three pectoral radials; poorly developed and floating or absent pleural ribs, especially posteriorly; one nostril on each side of the head; non-pungent fin spines; no swim bladder; two or three lateral lines (occasionally one); jugular pelvic fins; and nasal accessory organs $[30,65,66]$. While these character states are apomorphic compared to the ancestral percomorph condition $[30,33,66-68]$, they are also homoplastic and occur among various phylogenetically derived percomorph clades and should be regarded with some skepticism given "the rampant homoplasy that has characterized percomorph evolution, particularly at higher levels" ([33] p 22).

Table 1 provides the character states for morphological features used to diagnose notothenioids as a clade $[22,36,65,68,69]$. We emphasize the character states that differ between the early diverging non-Antarctic notothenioid lineages, Bovichtidae, Pseudaphritis and Eleginops, with those comprising the Antarctic Clade, and that might be shared with Percophis. For three characters, floating pleural ribs, number of nostrils and number of pectoral radials, Percophis exhibits the plesiomorphic percomorph state rather than the apomorphic state observed in notothenioids [30,31]. In Percophis, posterior pleural ribs articulate with the centra and are not floating. Floating ribs are known in other percomorph lineages including Trichonotus [62]. Percophis has two nostrils on each side of the head rather than the single nostril characteristic of notothenioids, which is also present in zoarcids and some groups formerly affiliated with zoarcids $[29,70]$. We note that Percophis has a wellossified skeleton that is similar to that of Bovichtidae and Pseudaphritis, which do not display the paedomorphic tendencies toward reduced skeletal ossification and persistence of cartilage that appear in Eleginops and all other notothenioids [71].

Regan ([72] p. 249) first noted the presence of three, versus four, radials in the pectoral girdle of notothenioids (Figure 3). There is confusion regarding the number of pectoral radials in Percophis, as Boulenger ([73] p. Figure 4 27B) and Pietsch ([31] Figure 2C) both illustrate the Percophis pectoral girdle with three radials, and Regan ([74] p. 851) states "the pectoral pterygials number three, one of which is attached to the coracoid in Ammodytes and two in Percophis". Our inspection of a cleared and alizarin stained specimen and other accounts in the literature, including Regan ([25] p. 140), show that Percophis has four pectoral radials [63]. Although small, the first (dorsal-most) radial in Percophis is definitely sutured off from the scapula as a distinct bone (Figure 3A). However, the first radial is less distinctly sutured off than in some other "trachinoid" lineages ([31] p. 260), possibly indicating that it is beginning the process of being ontogenetically lost by incorporation into the scapula. The loss of the first radial is complete in adult notothenioids, and even the nonAntarctic early diverging lineages Bovichtidae, Pseudaphritis and Eleginops, show no evidence of a suture between the anlage of the first radial and the scapula (Figure 3B-E).

Table 1 Character states for major morphological features of adult Percophis brasiliensis and major lineages of Notothenioidea based on radiographs, ethanol preserved and cleared and stained specimens

\begin{tabular}{|c|c|c|c|c|c|c|c|c|}
\hline & $\begin{array}{l}\text { Swim } \\
\text { bladder }\end{array}$ & $\begin{array}{l}\text { Floating posterior } \\
\text { pleural ribs }\end{array}$ & $\begin{array}{l}\text { Nostrils on each } \\
\text { side of head }\end{array}$ & $\begin{array}{l}\text { Pectoral } \\
\text { radials }\end{array}$ & $\begin{array}{l}\text { Ecto- } \\
\text { pterygoid } \\
\text { teeth }\end{array}$ & $\begin{array}{l}\text { Palatine } \\
\text { teeth }\end{array}$ & $\begin{array}{l}\text { Ocular } \\
\text { choroid } \\
\text { rete }\end{array}$ & $\begin{array}{l}\text { Persistent } \\
\text { choroid fissure }\end{array}$ \\
\hline \multicolumn{9}{|l|}{ Percophidae } \\
\hline Percophis brasiliensis & - & - & 2 & 4 & - & + & + & $?^{\mathrm{a}}$ \\
\hline \multicolumn{9}{|l|}{ Bovichtidae } \\
\hline Bovichtus diacanthus & - & + & 1 & 3 & - & + & + & + \\
\hline B. variegatus & - & + & 1 & 3 & - & + & + & + \\
\hline Cottoperca trigloides & - & + & 1 & 3 & - & + & + & + \\
\hline $\begin{array}{l}\text { Halaphritis } \\
\text { platycephala }^{\mathrm{b}}\end{array}$ & - & + & 1 & 3 & - & + & $?$ & $?$ \\
\hline \multicolumn{9}{|l|}{ Pseudaphritidae } \\
\hline Pseudaphritis urvillii & - & + & $1^{c}$ & 3 & $+{ }^{d}$ & + & + & - \\
\hline \multicolumn{9}{|l|}{ Eleginopsidae } \\
\hline Eleginops maclovinus & - & + & 1 & 3 & - & - & + & - \\
\hline Nototheniidae & - & + & 1 & 3 & - & - & + or- & $-^{e}$ \\
\hline $\begin{array}{l}\text { Other families of } \\
\text { Cryonotothenioidea }\end{array}$ & - & + & 1 & 3 & - & - & -or \pm & $-^{e}$ \\
\hline
\end{tabular}

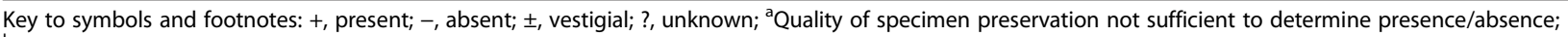
${ }^{b}$ Data from [48] and A.V. Balushkin (personal communication to J.T. Eastman on the presence of floating posterior pleural ribs in Halaphritis); ${ }^{\circ}$ Larvae of 16.5 mm SL have two nostrils ([76]: p. 64); ${ }^{d}$ In agreement with ([23] p. 43-44), ectopterygoid teeth were present in the three alizarin-stained specimens we examined; ${ }^{\mathrm{e}}$ Distal part of choroid fissure persists in Gobionotothen gibberifrons and Dolloidraco longedorsalis [111] 


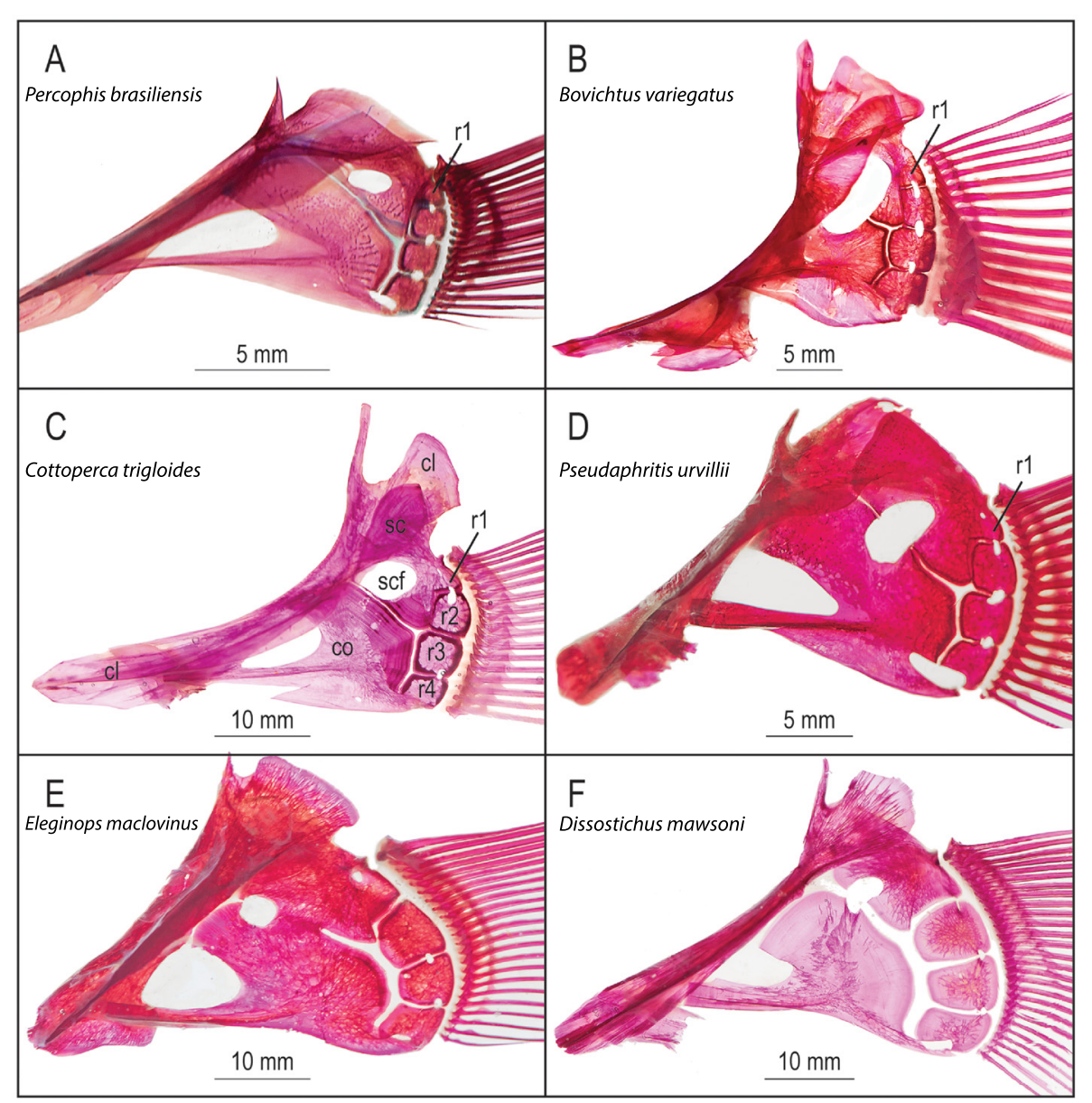

Figure 3 Pectoral girdle morphology in Percophis brasiliensis and five species of Notothenioidea. These are left lateral views of alizarin-stained girdles of (A) Percophis brasiliensis (SL = $115 \mathrm{~mm}$, UW 21233, the specimen illustrated in [31]); (B) Bovichtus variegatus (SL = $130 \mathrm{~mm}$ ); (C) Cottoperca trigloides ( $(\mathrm{SL}=217 \mathrm{~mm}$ ); (D) Pseudaphritis urvillii (SL = $180 \mathrm{~mm}$ ); (E) Eleginops maclovinus (SL = $260 \mathrm{~mm})$; and (F) Dissostichus mawsoni $(\mathrm{SL}=271 \mathrm{~mm})$. Bones are identified in panel $\mathbf{C}$ as follows: Cl, cleithrum; co, coracoid; r, radials 1-4; sC, scapula; scf, scapular foramen. In Percophis (A) the dorsal-most radial 1 is relatively small and the suture between it and the scapula is evident in both small (A) and large (243 mm SL) specimens [63]. In notothenioids (B-F), radial 1 is present in larvae but, after incorporation into the scapula during development and obliteration of the sutures, it is no longer discrete in adults. The R1 label in (B-D) does not indicate the presence of this radial in adults, but rather the approximate location of the anlage of radial 1. Percophis (A) plus Bovichtus (B), Cottoperca (C) and Pseudaphritis (D) differ from Eleginops (E) and Dissostichus (Cryonotothenioidea) (F) in several respects. In the latter, radials 2-4 are expanded and plate-like (E \& F). The maximum anteroposterior length of the pectoral girdle therefore shifts from the posterior margin radial 2 (A-D) to the posterior margin of enlarged radial 3 (E \& F). This shift changes the articulation pattern among the bones. In Percophis (A), Bovichtus (B), Cottoperca (C) and Pseudaphritis (D), radial 2 articulates with the scapula whereas in Eleginops and Cryonotothenioidea (E \& F), it meets both the scapula and the posterior margin of the coracoid [23]. The apparent gaps between individual bones in Dissostichus mawsoni (F) are filled in life by cartilage. The reduced intensity of the alizarin staining of the coracoid (F) of D. mawsoni is attributable to the spongy composition of the bone covering the cartilaginous core [71]. In this and other paedomorphic lineages, the pectoral girdle contains considerable persistent cartilage as ossification is delayed and, in some species, is never completed.

All species of notothenioid larvae studied to date have four pectoral radials prior to the fusion of the first radial with the scapula [75-78].

The first pectoral radial has been lost independently in many percomorph lineages [79]. Although still evident, the first radial is also in the process of becoming incorporated into the scapula in some "trachinoid" lineages including pinguipedids, specifically Pinguipes ([80] pp. 356-358, Figure 237) and in the creediid Tewara [81]. The first pectoral radial is fully incorporated into the scapula in several other percomorph lineages that, like notothenioids, possess only three radials as adults including Hemerocoetes ([29] Figure 11b), Callionymus ([79] p. 222), and Bembrops ([25] p. 141), although some species of Bembrops exhibit four radials ([29] p. 49). The recent development of molecular phylogenetic hypotheses for broad sampling of percomorph lineages provides an unusually comprehensive context to examine patterns of morphological evolution in the pectoral skeleton as well as other anatomical systems. 

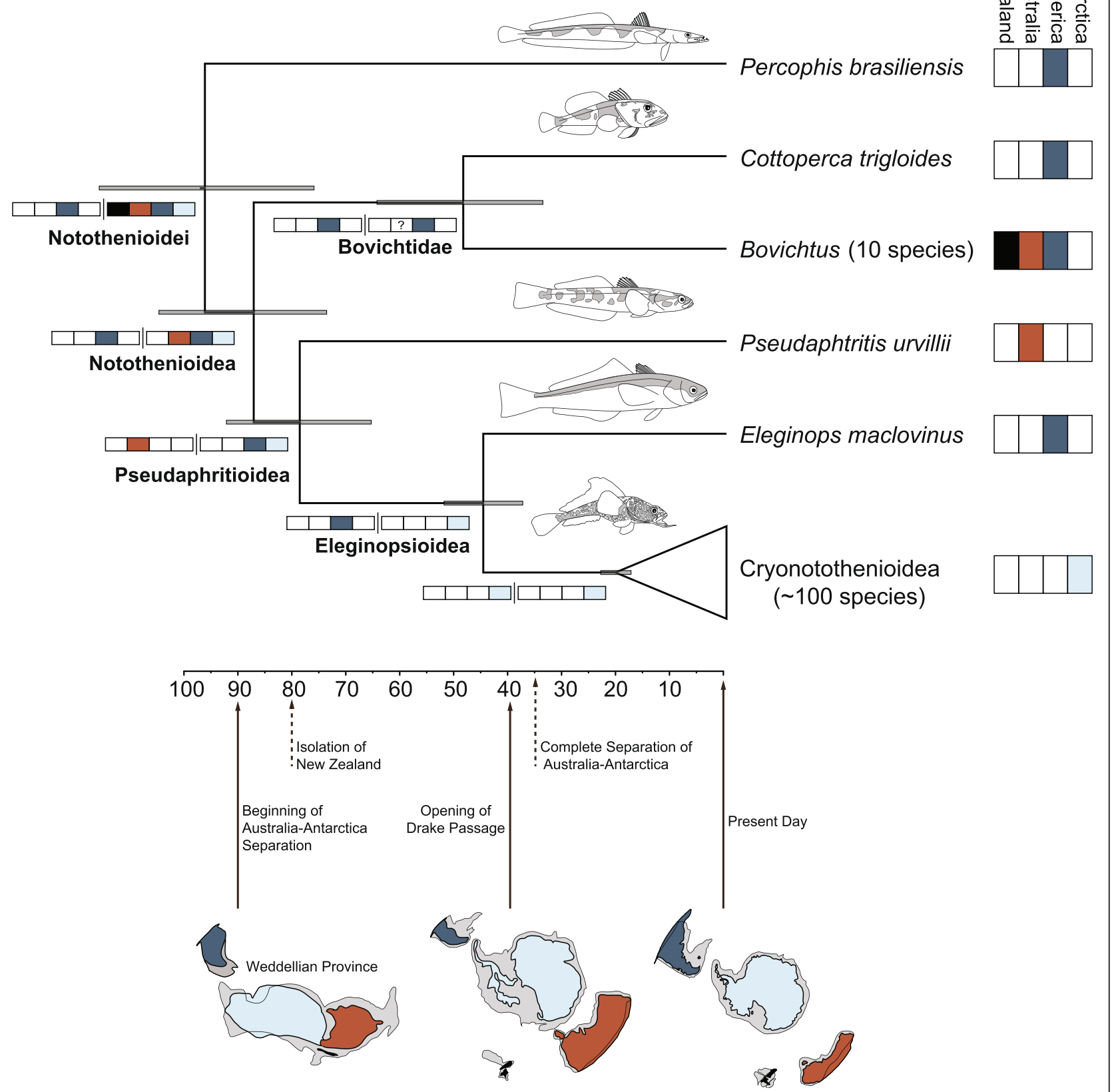

Figure 4 Time-calibrated phylogeny (X-axis in millions of years) and biogeographic reconstructions for the four-area Gondwanan model for Notothenioidei. The constrained maximum-likelihood biogeographic model included four areas corresponding to Gondwanan landmasses. New Zealand (black), Australia, (red), South America (blue) and Antarctica (light blue). The ancestral range shown at each internal node (colored boxes) are the reconstructed scenarios with the highest composite Akaike weight obtain analysis conducted on 1000 randomly chosen phylogenies from the posterior distribution of the Bayesian inferred time trees. The scenarios are drawn to reflect the splitting of the ancestral range due to the speciation event: the colored boxes to the left of the split (black line) represent the range inherited by the upper branch, with the colored boxes to the right of the split represent the range inherited by the lower branch. The timing of major paleogeographic events associated with the fragmentation of the Weddellian Province and East Gondwana are indicated along the x-axis. 


\section{Percomorph relationships and a new phylogenetic classification of Notothenioidei}

Based on the relationships supported in our molecular phylogenetic analysis (Figure 1), we propose several changes to the classification of Percomorpha that are rank-free and based on the principles of phylogenetic nomenclature [82-85]. We propose the name Cryonotothenioidea for the clade informally called the "Antarctic Clade" [8] or the "AFGP-bearing notothenioids" [24,44,52,86], which includes Artedidraconidae, Harpagifer, Channichthyidae, Bathydraconidae and Nototheniidae (Figure 1). We provide two additional names: the clade containing Eleginops and Cryonotothenioidea is Eleginopsioidea; and the clade containing Pseudaphritis and Eleginopsioidea is Pseudaphritioidea (Figure 1). We expand the traditional delimitation of Notothenioidei to include Percophis and apply the group name Notothenioidea to the clade containing Bovichtidae, Pseudaphritis, Eleginops and Cryonotothenioidea (Figure 1). The name Notothenioidea was previously applied to the clade we call Pseudaphritioidea [36].

Some ichthyologists are hesitant to accept taxonomic suggestions based on molecular phylogenetic analyses, preferring morphological evidence for all proposals regarding classification [87]. Since the early days of the 20th century there has been little doubt that Notothenioidea is a natural, or monophyletic, group $[13,26,72,88]$, a hypothesis consistently supported in molecular phylogenetic analyses [32,38,40,41,44]. Despite the confidence in notothenioid monophyly, it is interesting to note that the morphological characters in Table 1 used to define Notothenioidea are homoplastic when considered across the diversity of percomorph teleosts. Hence there is currently no unique character state that either diagnoses notothenioids or that could be used to identify a hypothesized sister lineage, such as Percophis, in a revised Notothenioidei (Figure 1). The absence of morphological synapomorphies supporting our new definition of Notothenioidei has no bearing on the merit of the hypothesis that Percophis and Notothenioidea share common ancestry, a conclusion supported by our molecular phylogeny and not refuted by morphology. The discovery of synapomorphic character states offering clear support that either Percophis or Notothenioidea shares common ancestry with other perciform or percomorph lineages would dispute the monophyly of Notothenioidei, but would still need to be evaluated in the context of other phylogenetic evidence, including molecular data.

\section{Biogeographic history of notothenioid diversification}

The first hypotheses aimed at determining the geographic origin of the Antarctic notothenioids were presented at the beginning of the 20th century [13,26,72,89]. Based on the observations that notothenioids dominate the fish fauna of the Southern Ocean, are relatively species rich and are ecologically and morphologically "peculiar" ([26] p. 40), Regan [26,72] hypothesized that Antarctica and the Southern Ocean were isolated "for a long time, probably throughout the Tertiary Period" ([26] p. 40). Regarding the potential for previous connections between South America, Antarctica and Australia, Regan concluded the distribution of notothenioids "throws no light on the question of former extensions northward of the Antarctic Continent" ([72] p. 2250). The distribution of early diverging non-Antarctic notothenioid lineages, Bovichtidae, Pseudaphritis and Eleginops, in South America, Australia and New Zealand was explained by dispersal [26,72]. However, this hypothesis was formed in the context of present-day continental configurations before the acceptance of plate tectonic theory.

From the Late Cretaceous through the early Cenozoic, South America, Antarctica Australia and New Zealand were connected in an area of cool temperate shallow seas known as the Weddellian Province [90-93], which has been suggested to comprise the ancestral area of notothenioids ([1] p. 133), [22,69] (Figure 4). Within the Weddellian Province, Balushkin [22] suggested the initial diversification of the notothenioids occurred on the Cretaceous coasts of New Zealand, Australia and Tasmania, a perspective based on the modern-day presence of Pseudaphritis, Halaphtritis, and Bovichtus, and a phylogenetic hypothesis that resolves Pseudaphritis as the sister lineage of all other Notothenioidea [22,48].

The combination of Bayesian divergence time information and a likelihood-based method of ancestral range estimation indicates that the formation of the geographic disjunctions observed today among the major notothenioid lineages closely followed the fragmentation of the landmasses encompassing the Weddellian Province (Figure 4, Table 2). This result was built into the DEC model used in our maximum likelihood estimation, given the use of four discrete time intervals to reflect the emergence of South America, New Zealand, Antarctica and Australia as distinct biogeographic regions (see Methods). However, the biogeographic reconstructions are very similar with the removal of these temporal constraints in the DEC analysis, which suggests a strong underlying biogeographic signal among the major notothenioid lineages.

The first unequivocal biogeographic movements within the notothenioids are associated with the separation of South America from East Gondwana, which, except for the opening of the Drake Passage, was nearly complete by $122 \mathrm{Ma}$ [94] (Figure 4, Table 2). Percophis is inferred to have originated in South America, which likely reflects a cladogenic event as the ancestral range expanded to include an isolated South American coastal area, Akaike weight $\left(w_{\mathrm{i}}\right)=0.942$. The ancestral range of Notothenioidea is inferred as the combination of ranges that comprised the Weddellian Province, and the diversification of the clade 
Table 2 The three best biogeographic reconstructions for each major notothenioid clade using lagrange

\begin{tabular}{|c|c|c|c|}
\hline Clade & Ancestral Rage & AIC Weight $\left(w_{i}\right)$ & Evidence Ratio \\
\hline \multirow[t]{3}{*}{ Notothenioidei } & $\mathrm{SA} \mid \mathrm{SA}, \mathrm{AU}, \mathrm{NZ}, \mathrm{AN}$ & 0.942 & \\
\hline & $S A \mid A U, N Z, A N$ & 0.028 & 33.21 \\
\hline & $N Z \mid S A, A U, A N$ & 0.020 & 47.28 \\
\hline \multirow[t]{3}{*}{ Notothenioidea } & $\mathrm{SA} \mid \mathrm{SA}, \mathrm{AU}, \mathrm{AN}$ & 0.467 & \\
\hline & $S A \mid S A, A N$ & 0.102 & 4.59 \\
\hline & $S A \mid S A, A U$ & 0.070 & 6.63 \\
\hline \multirow[t]{3}{*}{ Pseudaphritioidea } & $A U \mid S A, A N$ & 0.500 & \\
\hline & $A U \mid A U$ & 0.125 & 3.99 \\
\hline & $A N \mid S A, A N$ & 0.083 & 6.01 \\
\hline \multirow[t]{3}{*}{ Bovichtidae } & $S A \mid S A$ & 0.632 & \\
\hline & $S A \mid S A, A U$ & 0.130 & 4.88 \\
\hline & $S A \mid S A, A U, N Z$ & 0.101 & 6.31 \\
\hline \multirow[t]{3}{*}{ Eleginopsioidea } & SA $\mid A N$ & 0.637 & \\
\hline & $S A, A \cup \mid A N$ & 0.064 & 9.90 \\
\hline & $S A \mid A U, A N$ & 0.050 & 12.65 \\
\hline \multirow[t]{3}{*}{ Cryonotothenioidea } & AN | AN & 0.976 & \\
\hline & $A N \mid A U, A N$ & 0.011 & 88.54 \\
\hline & $A N \mid S A, A N$ & 0.009 & 111.69 \\
\hline
\end{tabular}

The reconstructions used a four-area Gondwanan model that included South America (SA), Australia (AU), New Zealand (NZ), and Antarctica (AN). The optimal ancestral range for each internal node (Figure 4) is listed first and the two less optimal reconstructions are italicized. The scenarios reflect the splitting of the ancestral range with areas to the left of the split represents the range inherited by the upper branch of the phylogeny in Figure 4 and ranges to the right of the split is the range inherited by the lower branch. For each reconstruction the Akaike weight $\left(w_{i}\right)$ and evidence ratio are listed.

involves cladogenesis between Bovichtidae, with an ancestral range of South America, and Pseudaphritioidea in the combined range of Antarctica, Australia and South America (Figure 4, Table 2). The timing of this disjunction, mean age $=88.6 \mathrm{Ma}, 95 \% \mathrm{HPD}=75.0,106.4 \mathrm{Ma}$, is very similar to the timing of the initial fragmentation of East Gondwana approximately $90 \mathrm{Ma}$ [95].

The biogeographic origin of the Pseudaphritioidea involves vicariance, specifically the fragmentation of Australia from the remaining East Gondwanan landmasses, $w_{\mathrm{i}}=0.500$ (Figure 4, Table 2). In this scenario, Pseudaphritis inherits Australia and the Eleginopsioidea inherit the combined area of Antarctica and South America (Figure 4). The estimated timing of diversification in the Pseudaphritioidea, mean $=80.1 \mathrm{Ma}, 95 \% \mathrm{HPD}=66.6$, 93.8 $\mathrm{Ma}$, is close to the initial fragmentation of Australia and Antarctica $90 \mathrm{Ma}$ [95], but much older than the complete separation of these two landmasses as indicated by the opening of the Tasmanian Seaway 35 Ma [96].

The timing of diversification in the Eleginopsioidea corresponds closely with the opening of the Drake Passage, which completed the separation of South America and Antarctica (Figure 4). In the most favored biogeographic scenario $\left(w_{\mathrm{i}}=0.637\right)$, the Cryonotothenioidea remained in Antarctica, while Eleginops inherited the South American portion of the ancestral geographic range (Figure 4, Table 2). The Eocene fossil taxon Proeleginops grandeastmanorum from Seymour Island, near the Antarctic Peninsula, provides paleontological support for the shared area of South America and Antarctica for Eleginopsioidea, as this taxon is thought to share common ancestry with the South America-Falkland Island endemic Eleginops maclovinus [97]. The age of the most recent common ancestor (MRCA) of Eleginopsioidea, mean $=45.6 \mathrm{Ma}, \mathrm{HPD}=38.2,53.0 \mathrm{Ma}$ is similar to the suggested timing (55-41 Ma) of the opening of the Drake Passage, the age of the formation bearing the $P$. grandeastmanorum fossil (52-47 Ma) [98], and the range of estimates for the initial formation of the Antarctic Circumpolar Current (41 to $23 \mathrm{Ma}$ ) $[99,100]$.

The estimates of notothenioid range evolution substantiate the previous supposition that the geographic distribution of the major lineages was shaped by the fragmentation of East Gondwana and that the Weddellian Province is the ancestral region of the clade $[1,22]$ (Figure 4, Table 2). Initial diversification of notothenioids is centered in the western portion of the Weddellian Province, particularly South America, involving two instances of vicariance in the MRCA of Percophis and the Notothenioidea and the MRCA of Bovichtidae and Pseudaphritioidea (Figure 4). An evaluation of the geographic distribution of Southern Ocean fishes led Andriashev in the 1960s to hypothesize that notothenioids originated in South America ([101] p. 542), but subsequent studies by 
Balushkin concluded the clade initially diversified in the eastern region of the Weddellian Province [22]. More recently the phylogeny of notothenioids and their geographic distribution was used to argue that the Antarctic continental shelf represents the ancestral area of notothenioids, as interpreted from a so called "center of origin" perspective [102]. Our new analyses synthesize knowledge of the phylogenetic relationships and geographic distribution of notothenioid species with the paleogeography of Eastern Gondwana to discriminate among these alternative biogeographic scenarios and provide the strongest support that the western Weddellian Province, centered on South America, was the area of initial diversification for the clade.

\section{Conclusions}

Phylogenetic analysis of DNA sequences sampled from 10 exon regions across a wide diversity of percomorph teleosts provides strong support for Percophis brasiliensis as the sister lineage of all other notothenioids (Figures 1 and 4). This result solves a century-old evolutionary puzzle, as the first scientists to describe the fish fauna of the Southern Ocean were unsure as to the relationships of notothenioids among the major lineages of percomorph teleosts $[13,26,72,89]$. The resolution of Percophis as the sister lineage of all other notothenioids is used to change the classification of percomorph fishes and contributes to the strong inference that southern South America, as associated with the western portion of the East Gondwana Weddellian Province, as the ancestral area of notothenioid diversification (Figure 4). The biogeographic history of notothenioid diversification estimated in our study illuminates the temporal and spatial circumstances that resulted in an interesting contrast between the species-depauperate relictual lineages Percophis, Bovichtidae, Pseudaphritis and Eleginops, with the eventual physical and climatic isolation of the Southern Ocean and the subsequent adaptive radiation of the species-rich Cryonotothenioidea.

\section{Methods}

Taxonomic sampling, DNA sequencing and phylogenetic analysis

The phylogenetic analyses in this study utilize DNA sequences of 10 nuclear protein coding genes sampled from all 550 species of Acanthomorpha included in Near et al. [40], expanded here to include 738 species. The taxon sampling includes 83 notothenioids [8], 101 species of Percidae [53] that includes Perca schrenkii, Gynocephalus cernuus, Romanichthys valsanicola and Zingel asper, which were sampled for this study, two species of the non-monophyletic Serranidae (Acanthistius cinctus and Liopropoma susumi) [37, 40], two species of Trachinidae (Trachinus draco and Echiichthys vipera), two species of Congiopodidae (Congiopodus leucopaecilus and
Zanclorhynchus spinifer), a species of Bembropidae (Chrionema furunoi), and two species of Percophidae (Pteropsaron springeri and Percophis brasiliensis). The addition of these newly sampled species to the taxon sampling in the Near et al. [40] dataset ensures that every lineage identified as the sister lineage of notothenioids is sampled and there is a dense sampling of lineages that comprise the Perciformes [sensu 10]. All field collection and processing of specimens followed the American Society of Ichthyologists and Herpetologists Guidelines for the Use of Fishes in Research (http://www.asih.org/publications).

Qiagen DNeasy Blood and Tissue kits were used to isolate DNA from tissue biopsies. Using isolated genomic DNA as a template previously published PCR primers $[103,104]$ were used to amplify and sequence a single exon from each of ten unlinked nuclear encoded genes ENC1, Glyt, myh6, plagl2, Ptr, rag1, SH3PX3, sreb2, tbr1 and zic1. These 10 protein coding gene regions were aligned by eye to the dataset used in Near et al. [40] and confirmed by examination of alignments of the inferred amino acid sequences. No frame mutations or DNA substitutions that resulted in stop codons were observed in the aligned sequences. The combined ten-gene dataset contained 8,577 base pairs. The outgroup taxa were the same set of seven sampled ostariophysan species used in Near et al. [40].

Thirty data partitions were designated that corresponded to the three separate codon positions for each of the ten protein coding genes. A GTR $+\Gamma_{4}$ substitution model was used in a partitioned maximum likelihood analysis using the computer program RAxML 7.2.6 [105], run with the D option, and 500 maximum likelihood searches. Support for nodes in the RAxML tree was assessed with a thorough bootstrap analysis (option $-\mathrm{f}$ i) with 500 replicates.

\section{Molecular divergence time estimates}

Relaxed molecular clock methods were used to estimate divergence times among major lineages of notothenioids and the sister lineage of the clade. Divergence time analyses were performed on a subset of seven species that included Percophis brasiliensis, which is resolved as the sister lineage of Notothenioidei, two species of Bovichtidae (Bovichtus diacanthus and Cottoperca trigloides), Pseudaphritis urvillii (the only species classified in Pseudaphritidae), Eleginops maclovinus (the only species classified in Eleginopsidae), and two species sampled to include the MRCA of Cryonotothenioidea (Dissostichus eleginoides and Chionobathyscus dewitti). Divergence times were estimated using the uncorrelated lognormal (UCLN) model of molecular evolutionary rate heterogeneity implemented in the computer program BEAST v. $1.8[106,107]$. The ten-gene dataset was partitioned as in the maximum likelihood RAxML phylogenetic analysis, unlinking the nucleotide substitution models 
among the 30 codon-based partitions and the UCLN clock model was partitioned among the 10 genes.

Based on the results of a previous UCLN analyses $[10,44]$, age priors with a normal distribution were applied to three nodes in the notothenioid phylogeny, which included the MRCA of Pseudaphritis urvillii and all other Eleginopsioidea $($ mean $=63.0$, standard deviation $=10.4)$, the MRCA of Eleginops maclovinus and the Antarctic clade $($ mean $=42.9$, standard deviation $=8.0)$, and the MRCA of the Antarctic clade (mean $=23.8$, standard deviation $=1.5$ ). The fossil notothenioid Proeleginops grandeastmanorum was not used as a calibration, as it would be the only fossil-based age prior [97]. However, the age priors used are the result of relaxed molecular clock analyses that broadly sampled the lineage diversity of acanthomorph and percomorph teleosts and used multiple non-notothenioid fossil calibrations [40, 44]. A birthdeath speciation prior was used for branching rates in the phylogeny. The BEAST analyses were run five times with each run consisting of $3.0 \times 10^{8}$ generations, sampling at every 10,000 generations. The resulting trees and log files from each of the five runs were combined using the computer program LogCombiner v. 1.8 (http://beast.bio.ed. ac.uk/LogCombiner). Convergence of model parameter values and estimated node-heights to their optimal posterior distributions was assessed by plotting the marginal posterior probabilities versus the generation state in the computer program Tracer v. 1.5 (http://beast.bio.ed.ac.uk/ Tracer). Effective sample size (ESS) values were calculated for each parameter to ensure adequate mixing of the MCMC (ESS > 200). The posterior probability density of the combined tree and log files was summarized as a maximum clade credibility tree using TreeAnnotator $\mathrm{v}$. 1.8 (http://beast.bio.ed.ac.uk/TreeAnnotator).

\section{Estimating the biogeographic history of notothenioids}

The dispersal-extinction-cladogenesis model (DEC) was used to estimate the biogeographic history for the major notothenioid lineages [108]. The DEC model assumes dispersal-mediated range expansion and extinctionmediated range contraction, with the probability of either event occurring along a particular branch being proportional to the length of that branch and the transition rates between geographic areas [108]. The transition rates and the reconstruction of the likeliest dispersal scenarios at all internal nodes under the DEC model were estimated using the $\mathrm{C}++$ version of lagrange.

We altered the migration probabilities among the four biogeographic regions in our model-Antarctica, South America, Australia or New Zealand-to reflect changes in connections to these areas during the gradual fragmentation of Gondwana. This involved devising separate migration matrices for four discrete time intervals: $150-80 \mathrm{Mya}$, 80-50 Mya, 50-30 Mya and 30-0 Mya. For the 150-80
Mya interval we assumed a zero probability of any movement our defined areas for the time period leading up to 80 Myr. This ensured that lineages were not estimated as being in Antarctica, South America, Australia or New Zealand in isolation when none of these regions technically existed. Non-zero probabilities for movement were allowed in the time interval of $80-50 \mathrm{Myr}$ to $\mathrm{New}$ Zealand and South America to reflect the isolation of the landmasses from the combined region of AustraliaAntarctica during this time period. From 50 to $30 \mathrm{Myr}$, the possibility of successful movements to Australia were allowed, as this was the time period in which it completed its separation from Antarctica. Finally, the 30-0 Mya interval reflected the emergence of the current geographic configuration of Antarctica, South America, Australia and New Zealand. The sensitivity of the reconstructions to the temporal constraints was examined by running the lagrange analysis with these constraints relaxed.

In order to assess the impact of both phylogenetic and temporal uncertainty on the ancestral range estimates, we inferred the most likely biogeographic scenarios across 1,000 randomly chosen trees obtained from the posterior distribution of time trees inferred using BEAST. We relied on a composite Akaike weights $\left(w_{\mathrm{i}}\right)$ as a means of summarizing biogeographic estimates of ancestral ranges across the posterior set of trees [109]. The composite Akaike weight $\left(w_{\mathrm{i}}\right)$ for a given scenario is the average of the individual Akaike weights calculated for each tree separately. Thus, we interpret the composite Akaike weight as describing the average relative likelihood of a given biogeographic scenario over a set of all possible alternative scenarios [109]. As lagrange only reports ancestral area estimates that are less than two-log likelihood units away from the inferred global likelihood, we utilized a modified version of lagrange that outputs the likelihood of all possible biogeographic scenarios estimated at a focal node [109] that has also been used in other biogeographic studies [110].

\section{Availability of supporting data}

The data sets supporting the results of this article are available in the Dryad repository, [doi:http://dx.doi.org/ 10.5061/dryad.s355k]. All new DNA sequences are submitted to Genbank (KP965919-KP966072).

\section{Competing interests}

The authors declare that they have no competing interests.

\section{Authors' contributions}

All authors contributed to the overall design and scope of the project. CO, TPS, EK, CET, PCW and TJN carried out fieldwork for specimen collection. TJN, AD and $\mathrm{RCH}$ were responsible for the collection, assembly and curation of the molecular phylogenetic dataset. TJN, AD, RCH and JMB performed the phylogenetic analyses. JMB, JTE and TJN set up and performed the biogeographic analyses. JTE, TWP, and TJN assembled and interpreted the morphological information. The primary draft of the manuscript was written by TJN and AD. All authors contributed to the completion of the final draft of the manuscript. 


\section{Acknowledgments}

Fieldwork in the Southern Ocean was facilitated through C. D. Jones of the United States Antarctic Marine Living Resources Program and the officers and crew of the RV Yuzhmorgeologia, and the 2004 ICEFISH cruise aboard the RVIB Nathaniel B. Palmer that was funded through a National Science Foundation (NSF) grant (OPP 01-32032) to H.W. Detrich III. Field and laboratory support was provided by H.W. Detrich, J. Kendrick, K.-H. Kock, J.A Moore and A. L. Stewart. A. Dettaï and G. Lecointre of the Muséum National $d^{\prime}$ Histoire Naturelle, Paris, France and C.D. Roberts of the Museum of New Zealand Te Papa Tongarewa provided critical specimens. CO is a Conselho Nacional de Desenvolvimento Científico e Tecnológico do Brasil researcher (CNPq grant number 309632/2007-2) and collections in Brazil were founded by Fundação de Amparo à Pesquisa do Estado de São Paulo (FAPESP grant number 2008/08294-5) and authorized by Ministerio do Meio Ambiente (IBAMA license number 13843-1). Karsten Hartel (Museum of Comparative Zoology, Harvard University), Nelson Rios and Justin Mann (Tulane University), and Katherine Maslenikov (University of Washington) provided loans of museum specimens. This research was funded from NSF grants awarded to TJN (ANT-1341661) and JTE (ANT-0436190).

\section{Author details}

'Department of Ecology and Evolutionary Biology, Yale University, New Haven, CT 06520, USA. ${ }^{2}$ Yale Peabody Museum of Natural History, New Haven, CT 06520, USA. ' Department of Earth Sciences, University of Oxford, South Parks Road, Oxford OX1 3AN, UK. ${ }^{4}$ Department Morfologia, Instituto de Biociências, Universidade Estadual Paulista, Botucatu, São Paulo, Brazil. ${ }^{5}$ School of Aquatic and Fishery Sciences and Burke Museum of Natural History and Culture, University of Washington, Seattle, WA 98105, USA. ${ }^{6}$ Research and Collections, Section of Ichthyology, Natural History Museum of Los Angeles County, 900 Exposition Blvd., Los Angeles, CA 90007, USA. ${ }^{7}$ National Museum of Nature and Science, Tsukuba City, Ibaraki 305-0005, Japan. ${ }^{8}$ Section of Evolution \& Ecology, University of California, Davis, CA 95616, USA. ${ }^{\circ}$ Department of Biomedical Sciences, Ohio University, Athens, $\mathrm{OH}$ 45701-2979, USA. ${ }^{10}$ National Institute for Mathematical and Biological Synthesis, University of Tennessee, 1122 Volunteer Blvd, Ste. 106, Knoxville, TN 37996, USA.

\section{Received: 8 December 2014 Accepted: 27 April 2015} Published online: 11 June 2015

\section{References}

1. Eastman JT. Antarctic Fish Biology: Evolution in a Unique Environment. San Diego: Academic; 1993.

2. Eastman JT. The nature of the diversity of Antarctic fishes. Polar Biol. 2005;28:93-107.

3. Croxall JP, Nicol S. Management of Southern Ocean fisheries: global forces and future sustainability. Antarctic Sci. 2004;16:569-84.

4. O'Brien KM, Crockett EL. The promise and perils of Antarctic fishes-the remarkable life forms of the Southern Ocean have much to teach science about survival, but human activity is threatening their existence. Embo Rep. 2013:14:17-24.

5. Ainley DG, Pauly D. Fishing down the food web of the Antarctic continental shelf and slope. Polar Rec. 2014;50:92-107.

6. Barrera-Oro E. The role of fish in the Antarctic marine food web: differences between inshore and offshore waters in the southern Scotia Arc and west Antarctic Peninsula. Antarctic Sci. 2002;14:293-309.

7. La Mesa M, Eastman JT, Vacchi M. The role of notothenioid fish in the food web of the Ross Sea shelf waters: a review. Polar Biol. 2004;27:321-38.

8. Near TJ, Dornburg A, Kuhn KL, Eastman JT, Pennington JN, Patarnello T, et al. Ancient climate change, antifreeze, and the evolutionary diversification of Antarctic fishes. Proc Nat Acad Sci USA. 2012;109:3434-9.

9. Chen L, DeVries AL, Cheng C-HC. Evolution of antifreeze glycoprotein gene from a trypsinogen gene in Antarctic notothenioid fish. Proc Nat Acad Sci USA. 1997:94:3811-6.

10. Near TJ, Eytan RI, Dornburg A, Kuhn KL, Moore JA, Davis MP, et al. Resolution of ray-finned fish phylogeny and timing of diversification. Proc Nat Acad Sci USA. 2012;109:13698-703.

11. Janko K, Marshall C, Musilova Z, Van Houdt J, Couloux A, Cruaud C, et al. Multilocus analyses of an Antarctic fish species flock (Teleostei, Notothenioidei, Trematominae): phylogenetic approach and test of the early-radiation event. Mol Phylogenet Evol. 2011;60:305-16.
12. Rutschmann S, Matschiner M, Damerau M, Muschick M, Lehmann MF, Hanel $R$, et al. Parallel ecological diversification in Antarctic notothenioid fishes as evidence for adpative radiation. Mol Ecol. 2011;20:4707-21.

13. Dollo L. Poissons. Expedition antarctique Belge. Resultats du voyage du S. Y. Belgica en 1897-1898-1899 sous le commandement de A. de Gerlache de Gomery. Antwerp: J.-E. Buschmann; 1904.

14. Near TJ, Cheng C-HC. Phylogenetics of notothenioid fishes (Teleostei: Acanthomorpha): inferences from mitochondrial and nuclear gene sequences. Mol Phylogenet Evol. 2008;47:832-40.

15. Near TJ, Pesavento JJ, Cheng CHC. Phylogenetic investigations of Antarctic notothenioid fishes (Perciformes: Notothenioidei) using complete gene sequences of the mitochondrial encoded 165 rRNA. Mol Phylogenet Evol. 2004;32:881-91.

16. Dettaï A, Berkani M, Lautredou AC, Couloux A, Lecointre G, Ozouf-Costaz C, et al. Tracking the elusive monophyly of nototheniid fishes (Teleostei) with multiple mitochondrial and nuclear markers. Marine Genomics. 2012;8:49-58.

17. Bargelloni L, Marcato S, Zane L, Patarnello T. Mitochondrial phylogeny of notothenioids: a molecular approach to Antarctic fish evolution and biogeography. Syst Biol. 2000;49:114-29.

18. Bargelloni L, Ritchie PA, Patarnello T, Battaglia B, Lambert DM, Meyer A Molecular evolution at subzero temperatures: mitochondrial and nuclear phylogenies of fishes from Antarctica (Suborder Notothenioidei), and the evolution of antifreeze glycopeptides. Mol Biol Evol. 1994;11:854-63.

19. Derome N, Chen W-J, Dettai A, Bonillo C, Lecointre G. Phylogeny of Antarctic dragonfishes (Bathydraconidae, Notothenioidei, Teleostei) and related families based on their anatomy and two mitochondrial genes. Mol Phylogenet Evol. 2002;24:139-52.

20. Lecointre G, Bonillo C, Ozouf-Costaz C, Hureau J-C. Molecular evidence for the origins of Antarctic fishes: paraphyly of the Bovichtidae and no indication for the monophyly of the Notothenioidei (Teleostei). Polar Biol. 1997:18:193-208.

21. Lecointre G, Gallut C, Bonillo C, Couloux A, Ozouf-Costaz C, Dettai A. The Antarctic fish genus Artedidraco is paraphyletic (Teleostei, Notothenioidei, Artedidraconidae). Polar Biol. 2011;34:1135-45.

22. Balushkin AV. Morphology, classification, and evolution of notothenioid fishes of the Southern Ocean (Notothenioidei, Perciformes). J Ichthyol. 2000;40:S74-109.

23. Iwami T. Osteology and relationships of the family Channichthyidae. Mem Nat Inst Polar Res Tokyo. 1985;36:1-69.

24. Lecointre G. Phylogeny and Systematics of Antarctic Teleosts: Methodological and Evolutionary Issues. In: Prisco G, Verde C, editors. Adaptation and Evolution in Marine Environments, Volume 1, From Pole to Pole. Berlin: Springer; 2012. p. 97-117.

25. Regan CT. The classification of the percoid fishes. Ann Mag Nat Hist 1913;12:111-45.

26. Regan CT. Fishes. British Antarctic Terra Nova Expedition 1910. Natural History Report Zoology. 1914;1:1-54.

27. Dettaï A, Lecointre G. In search of notothenioid (Teleostei) relatives. Antarctic Sci. 2004;16:71-85.

28. Anderson ME. The Origin and Evolution of the Antarctic Ichthyofauna. In: Gon O, Heemstra PC, editors. Fishes of the Southern Ocean. Grahamstown, South Africa: J.L.B. Smith Institute of Ichthyology; 1990. p. 28-33.

29. Gosline WA. The suborders of perciform fishes. Proc US Nat Mus. 1968:124:1-78.

30. Hastings PA. Relationships of Fishes of the Perciform Suborder Notothenioidei. In: Miller RG, editor. A History and Atlas of the Fishes of the Antarctic Ocean. Carson City: Foresta Institute for Ocean and Mountain Studies; 1993. p. 99-107.

31. Pietsch TW. Phylogenetic relationships of trachinoid fishes of the family Uranoscopidae. Copeia. 1989;1989:253-303.

32. Chen WJ, Bonillo C, Lecointre G. Repeatability of clades as a criterion of reliability: a case study for molecular phylogeny of Acanthomorpha (Teleostei) with larger number of taxa. Mol Phylogenet Evol. 2003;26:262-88.

33. Johnson GD. Percomorph phylogeny: progress and problems. Bull Mar Sci. 1993;52:3-28.

34. Mooi RD, Johnson GD. Dismantling the Trachinoidei: evidence of a scorpaenoid relationship for the Champsodontidae. Ichthyol Res. 1997;44:143-76.

35. Boulenger GA. Notes on the classification of teleostean fishes-I. On the Trachinidae and their allies. Ann Mag Nat Hist. 1901;7(8):261-71. 
36. Voskoboinikova OS. Ontogenetic bases of the origin and relationships of the fishes from the suborder Notothenioidei (Perciformes). J Ichthyol. 2004;44:464-79.

37. Smith WL, Craig MT. Casting the percomorph net widely: the importance of broad taxonomic sampling in the search for the placement of serranid and percid fishes. Copeia. 2007;2007:35-55.

38. Lautredou A-C, Motomura H, Gallut C, Ozouf-Costaz C, Cruaud C, Lecointre $G$, et al. New nuclear markers and exploration of the relationships among Serraniformes (Acanthomorpha, Teleostei): the importance of working at multiple scales. Mol Phylogenet Evol. 2013;67:140-55.

39. Betancur-R. R, Broughton RE, Wiley EO, Carpenter K, López JA, Li C, Holcroft NI, et al. The Tree of Life and a New Classification of Bony Fishes. PLOS Currents Tree of Life. 2013 Apr 18. Edition 1. doi:10.1371/ currents.tol.53ba26640df0ccaee75bb165c8c26288.

40. Near TJ, Dornburg A, Eytan RI, Keck BP, Smith WL, Kuhn KL, et al. Phylogeny and tempo of diversification in the superradiation of spiny-rayed fishes. Proc Nat Acad Sci USA. 2013:110:12738-43.

41. Dettaï A, Lecointre G. Further support for the clades obtained by multiple molecular phylogenies in the acanthomorph bush. C R Biol. 2005;328:647-89.

42. Smith WL, Wheeler WC. Polyphyly of the mail-cheeked fishes (Teleostei : Scorpaeniformes): evidence from mitochondrial and nuclear sequence data. Mol Phylogenet Evol. 2004:32:627-46.

43. Li B, Dettai A, Cruaud C, Couloux A, Desoutter-Meniger M, Lecointre G. RNF213, a new nuclear marker for acanthomorph phylogeny. Mol Phylogenet Evol. 2009;50:345-63.

44. Matschiner M, Hanel R, Salzburger W. On the origin and trigger of the notothenioid adaptive radiation. Plos One. 2011;6:e18911.

45. Cheng C-HC. Evolution of the diverse antifreeze proteins. Current Opinion in Genetics and Development. 1998:8:715-20.

46. Ceballos SG, Lessa EP, Victorio MF, Fernandez DA. Phylogeography of the sub-Antarctic notothenioid fish Eleginops maclovinus: evidence of population expansion. Mar Biol. 2012;159:499-505.

47. Hardy GS. A revision of Bovichtus Cuvier, 1831 (Pisces: Bovichthyidae) from Australasia, with description of a new deepwater species from the New Zealand Subantarctic. J Nat Hist. 1988;22:1639-55.

48. Last PR, Balushkin AV, Hutchins JB. Halaphritis platyrephala (Notothenioidei: Bovichtidae): a new genus and species of temperate icefish from Southeastern Australia. Copeia. 2002;2002:433-40.

49. Norman JR. Coast fishes. Part II. The Patagonian region. Discorery Rep. $1937 ; 16: 1-150$

50. Bravo R, Lloris D, Pequeño G, Rucabado J. Revisión de las distintas especies del género Bovichtus (Perciformes, Bovichtidae) citadas para el cono sur americano y península Antártica. Rev Biol Mar Oceanogr. 1999;34:123-37.

51. Pequeño G, Inzunza AJ. Variabilidad intraespecifica y status sistematico del "torito" Bovichthys chilensis Regan 1913 (Osteichthyes, Bovichthyidae) en Valdivia, Chile. Bol Soc Bio Concepción. 1987;58:127-39.

52. Near TJ. Estimating divergence times of notothenioid fishes using a fossil-calibrated molecular clock. Antarctic Sci. 2004;16:37-44.

53. Near TJ, Keck BP. Free from mitochondrial DNA: Nuclear genes and the inference of species trees among closely related darter lineages (Teleostei: Percidae: Etheostomatinae). Mol Phylogenet Evol. 2013;66:868-76.

54. Friedman $M$, Keck BP, Dornburg A, Eytan Rl, Martin $C H$, Hulsey CD, et al. Molecular and fossil evidence place the origin of cichlid fishes long after Gondwanan rifting. Proc R Soc B. 2013;280:20131733.

55. Ribeiro AD, Caires RA, Mariguela TC, Pereira LHG, Hanner R, Oliveira C. DNA barcodes identify marine fishes of Sao Paulo State, Brazil. Mol Ecol Resour. 2012;12:1012-20.

56. Ward RD, Holmes BH. An analysis of nucleotide and amino acid variability in the barcode region of cytochrome c oxidase I (cox1) in fishes. Mol Ecol Notes. 2007;7:899-907.

57. Nelson JS. Fishes of the world. 4th ed. Hoboken: John Wiley; 2006

58. Imamura H, Odani K. An overview of the phylogenetic relationships of the suborder Trachinoidei (Acanthomorpha: Perciformes). Ichthyol Res. 2013;60:1-15.

59. Greenwood PH, Rosen DE, Weitzman SH, Myers GS. Phyletic studies of teleostean fishes, with a provisional classification of living forms. Bull Amer Mus Nat Hist. 1966;131:341-455.

60. Odani K, Imamura H. New phylogenetic proposal for the Family Leptoscopidae (Perciformes: Trachinoidei). Bulletin of Fisheries Sciences Hokkaido University. 2011;61:49-63.
61. Smith DG, Johnson GD. A new species of Pteropsaron (Teleostei: Trichonotidae: Hemerocoetinae) from the western Pacific, with notes on related species. Copeia. 2007;2007:364-77.

62. Nelson JS. Some characters of Trichonotidae, with emphasis to those distinguishing it from Creediidae (Perciformes, Trachinoidei). Jap J Ich. 1986;33:1-6.

63. Odani K, Imamura H, Nakaya K. Osteological description of the Brazilian flathead, Percophis brasiliensis (Actinopterygii: Perciformes: Percophidae), with comments on its phylogenetic position. Spec Div. 2006;11:277-94.

64. Pietsch TW, Zabatien CP. Osteology and interrelationships of the sand lances (Teleostei: Ammodytidae). Copeia. 1990;1990:78-100.

65. Eakin RR. Osteology and Relationships of the Fishes of the Antarctic family Harpagiferidae (Pisces, Notothenioidei). In: Kornicker LS, editor. Antarctic Research Series, Vol 31, Biology of the Antarctic Seas IX. Washington: American Geophysical Union; 1981. p. 81-147.

66. Iwami T. A note on the nasal structures of fishes of the suborder Notothenioidei (Pisces, Perciformes). Mem Natl Inst Polar Res, Spec Issue. 1985;44:151-2

67. Johnson GD, Patterson C. Percomorph phylogeny: a survey of acanthomorphs and a new proposal. Bull Mar Sci. 1993;52:554-626.

68. Wiley EO, Johnson GD. A Teleost Classification based on Monophyletic Groups. In: Nelson JS, Schultze H-P, Wilson MVH, editors. Origin and Phylogenetic Interrelationships of Teleosts. Munchen: Verlag Dr. Friedrich Pfeil; 2010. p. 123-82.

69. Balushkin AV. Classification, phylogenetic relationships, and origins of the families of the suborder Notothenioidei (Perciformes). J Ichthyol. 1992;32(7):90-110.

70. Anderson ME. Zoarcidae. In: Gon O, Heemstra PC, editors. Fishes of the Southern Ocean. Grahamstown, South Africa: J.L.B. Smith Institute of Ichthyology; 1990. p. 256-76.

71. Eastman JT, Witmer LM, Ridgely RC, Kuhn KL. Divergence in skeletal mass and bone morphology in Antarctic notothenioid fishes. J Morph. 2014;275:841-61.

72. Regan CT. The Antarctic fishes of the Scottish National Antarctic Expedition. Transactions of the Royal Society of Edinburgh. 1913;49:229-92.

73. Boulenger GA. Teleostei. Cambridge Natural History. 1904;7:539-727.

74. Regan CT. Notes on the Classification of Teleostean Fishes. In: Proceedings of the Seventh International Zoological Congress, Boston, 19-24 August, 1907. Cambridge: University Press; 1912. p. 838-53.

75. Voskoboinikova OS. Osteological development of the Channichthyidae (Teleostei: Notothenioidei). Cybium. 1997;21:369-79.

76. Voskoboinikova OS, Bruce B. Development of bony skeleton during ontogeny of Bovichtus angustifrons (Bovichtyidae, Notothenioidei) with comparative notes on development of bony skeleton of congolli Pseudaphritis urvilli (Pseudaphritidae). J Ichthyol. 2001;41:57-66.

77. Voskoboinikova OS, Kellermann A. The osteological development of nine species of Nototheniidae (Perciformes: Notothenioidei). Cybium. 1997;21:231-64.

78. Voskoboinikova OS, Tereshchuk OY, Kellermann A. Osteological development of the Antarctic silverfish Pleurogramma antarcticum (Nototheniidae). Cybium. 1994;18:251-71.

79. Starks EC. The primary shoulder girdle of the bony fishes. Stanford University Publications Biological Sciences. 1930;6:149-239.

80. Gregory WK. Fish skulls: a study of the evolution of natural mechanisms. Trans Amer Phil Soc. 1933;23:75-481.

81. Nelson JS. On the interrelationships of the genera of Creediidae (Perciformes, Trachinoidei). Jap J Ich. 1985:32:283-93.

82. Cantino PD, de Queiroz K. PhyloCode: A Phylogenetic Code of Biologica Nomenclature. Version 4b. http://www.ohio.edu/phylocode/ 2009.

83. de Queiroz K, Gauthier J. Phylogeny as a central principle in taxonomy: Phylogenetic definition of taxon names. Syst Zool. 1990;4:307-22.

84. de Queiroz K, Gauthier J. Phylogenetic taxonomy. Annu Rev Ecol Syst. 1992;23:449-80.

85. de Queiroz K, Gauthier J. Toward a phylogenetic system of biological nomenclature. Trends Ecol Evol. 1994;9:27-31.

86. Desser SS, Mclver, Ryckman. Culex teritans as a potential vector of Trypanosoma rotatorium. I. Development of the flagellate in the mosquito. Journal of Parasitology. 1973;59:353-8.

87. Mooi RD, Gill AC. Phylogenies without synapomorphies-a crisis in fish systematics: time to show some character. Zootaxa. 2010;2450:26-40.

88. Boulenger GA. Pisces. In: Report on the Collections of Natural History made in the Antarctic Regions during the Voyage of the 'Southern Cross'. London: British Museum (Natural History); 1902. p. 174-89. 
89. Lönnberg E. The fishes of the Sweedish South Polar Expedition. Wiss Ergebn Schwed Südpol Exped 1901-1903. 1905;5:1-69.

90. Zinsmeister WJ. Biogeographic Significance of the Late Mesozoic and Early Tertiary Molluscan Fauna of Seymour Island (Antarctic Peninsula) to the Final Breakup of Gondwanaland. In: Gray J, Boucot AJ, editors. Historical Biogeography, Plate Tectonics, and the Changing Environment. Corvallis: Oregon State University; 1979. p. 349-55.

91. Zinsmeister WJ. Late cretaceous - early tertiary molluscan biogeography of the southern circum-Pacific. J Paleontol. 1982;56:84-102.

92. Reguero M, Goin F, Hospitaleche CA, Dutra T, Marenssi S. Late Cretaceous/ Paleogene West Antarctica Terrestrial Biota and its Intercontinental Affinities. Dordrecht: Springer; 2013.

93. Woodburne MO, Zinsmeister WJ. The first land mammal from Antarctica and its biogeographic implications. J Paleontol. 1984;58:913-48.

94. Jokat W, Boebel T, Konig M, Meyer U. Timing and geometry of early Gondwana breakup. J Geophys Res-Sol Ea. 2003;108:2428.

95. Blakey RC. Gondwana paleogeography from assembly to breakup-A 500 m.y. odyssey. Geolog Soc Amer Spec Pap. 2008:441:1-28.

96. Stickley CE, Brinkhuis H, Schellenberg SA, Sluijs A, Rohl U, Fuller M, Grauert M, Huber M, Warnaar J, Williams GL. Timing and nature of the deepening of the Tasmanian Gateway. Paleoceanography. 2004;19:PA4027.

97. Balushkin AV. Proeleginops grandeastmanorum gen. et sp. nov. (Perciformes, Notothenioidei, Eleginopsidae) from the Late Eocene of Seymour Island (Antarctica) is a fossil notothenioid, not a gadiform. J Ichthyol. 1994;34:10-23.

98. Ivany LC, Lohmann KC, Hasiuk F, Blake DB, Glass A, Aronson RB, et al. Eocene climate record of a high southern latitude continental shelf: Seymour Island, Antarctica. Geol Soc Am Bull. 2008;120:659-78.

99. Scher HD, Martin EE. Timing and climatic consequences of the opening of Drake Passage. Science. 2006;312:428-30.

100. Barker PF, Filippelli GM, Florindo F, Martin EE, Scher HD. Onset and role of the Antarctic Circumpolar Current. Deep-Sea Res Pt II. 2007;54:2388-98.

101. Andriashev AP. A General Review of the Antarctic Fish Fauna. In: Mieghem J, Oye P, editors. Biogeography and Ecology in Antarctica. The Hague: Junk; 1965. p. 491-550.

102. Briggs JC, Bowen BW. Marine shelf habitat: biogeography and evolution. J Biogeogr. 2013;40:1023-35.

103. Li CH, Ortí G, Zhang G, Lu GQ. A practical approach to phylogenomics: the phylogeny of ray-finned fish (Actinopterygii) as a case study. BMC Evol Biol. 2007;7:44.

104. Lopez JA, Chen WJ, Ortí G. Esociform phylogeny. Copeia. 2004;2004:449-64

105. Stamatakis A. RAxML-VI-HPC: maximum likelihood-based phylogenetic analyses with thousands of taxa and mixed models. Bioinformatics. 2006;22:2688-90.

106. Drummond AJ, Rambaut A. BEAST: Bayesian evolutionary analysis by sampling trees. BMC Evol Biol. 2007;7:214.

107. Drummond AJ, Ho SYW, Phillips MJ, Rambaut A. Relaxed phylogenetics and dating with confidence. PLOS Biol. 2006;4:699-710.

108. Ree $\mathrm{RH}$, Smith SA. Maximum likelihood inference of geographic range evolution by dispersal, local extinction, and cladogenesis. Syst Biol. 2008:57:4-14.

109. Beaulieu JM, Tank DC, Donoghue MJ: A Southern Hemisphere origin for campanulid angiosperms, with traces of the break-up of Gondwana. BMC Evol Biol. 2013;13:80.

110. Dornburg A, Moore JA, Beaulieu JM, Eytan RI, Near TJ. The impact of shifts in marine biodiversity hotspots on patterns of range evolution: evidence from the Holocentridae (Squirrelfishes and Soldierfishes). Evolution. In press.

111. Eastman JT. Aspects of the morphology of phyletically basal bovichtid fishes of the Antarctic suborder Notothenioidei (Perciformes). Polar Biol. 2006:29:754-63.

\section{Submit your next manuscript to BioMed Central and take full advantage of:}

- Convenient online submission

- Thorough peer review

- No space constraints or color figure charges

- Immediate publication on acceptance

- Inclusion in PubMed, CAS, Scopus and Google Scholar

- Research which is freely available for redistribution 